\title{
The Most Common Microbial agents of Urinary Infection and Pattern of Antibiotical Sensitivity in Patients Referred to the Central Laboratory of ShahreKord
}

\author{
Jamshid Ayatollahi ${ }^{1}$, Fatemeh Mohammadi ${ }^{2}$, Seyed Alireza Mousavi ${ }^{1}$, Mahdie Hamidfar ${ }^{1}$, \\ Seyed Hossein Shahcheraghi ${ }^{1 *}$
}

1 Infectious Diseases Research Center, Shahid Sadoughi Hospital, Shahid Sadoughi University of Medical Sciences, Yazd, Iran

2 Medical Student, Shahid Sadoughi University of Medical Sciences, Yazd, Iran

*Corresponding Author: Seyed Hossein Shahcheraghi, Infectious Diseases Research Center, Shahid Sadoughi Hospital, Shahid Sadoughi University of Medical Sciences, Yazd, Iran.

Email: shahcheraghih@gmail.com; Tel: 00989132531389

Received: June 15, 2021; Accepted: July 18, 2021

\begin{abstract}
Urinary tract infections (UTI) are the second common infections, worldwide after respiratory infections. So understanding causes and treatment of these infections is necessary to prevent complications. The aim of this study was to investigate common microbial causes of UTI and antibiotic sensitivity pattern of patients referred to the central laboratory of ShahreKord city during 2020. This study was as descriptive and cross-sectional. Data collection was based on the data of the registry of positive samples of urinary tract infections and based on the studies performed in the laboratory, in terms of the type of pathogen and the type of antibiotic. Data were based on name, age, sex, test result, type of bacteria, and pattern of drug resistance or susceptibility. Finally, SPSS software (version 22) was applied for analyzing. Results showed that $8.2 \%$ tests were positive. More positive tests were in the summer season. Escherichia coli had the highest frequency. The lowest resistance was related to gentamicin and the highest resistance was related to ampicillin. Therefore, it is vital that ampicillin consumption should be decreased in urinary infection caused by Escherichia coli in ShahreKord.
\end{abstract}

Keywords: Urinary tract infections, Antibiotic sensitivity, Resistance.

\section{INTRODUCTION}

Urinary tract infection (UTI) is one of the most usual infectious diseases faced by physicians and clinicians in spite of the extensive accessibility of antimicrobials UTI has become hard to cure due to entrance of microbes with enhancing resistance to antibacterial agents ${ }^{[1-5]}$.

Certainly, UTIs are the important reason of bacteremia by gramnegative bacteria in cases of all age groups and are related to a great danger of mortality, particularly in the old patients ${ }^{[6-10]}$.

More UTI cases are not human life frightening and do not create any irremediable injury [11]. Nevertheless, when the kidneys are complicated, there is a danger of irremediable tissue hurt with an enhanced hazard of advanced bacteremia ${ }^{[12-15]}$.
Resistance amounts to the most usual used drugs in the management of treatment of UTIs differ noticeably in different parts of world. The approximation of etiology and sensitivity outline can provide better vision for treatment by antibiotics [1619].

The present study was aimed at evaluation of the common microbial agents of urinary infection and pattern of antibiotical sensitivity in patients in a city of Iran.

\section{MATERIALS AND METHODS}

In this descriptive cross-sectional study, the study population included all people who underwent urine culture in the central 
laboratory of Shahrekord in 2020. This research was approved by the Ethics Committee of Shahid Sadoughi University of medical sciences, Yazd.

Sampling was by census. Data collection was based on the data of the registry of positive samples of urinary tract infections and based on the studies performed in the laboratory, in terms of the type of pathogen and the type of antibiotic and was studied according to the intended objectives and approved by the supervisor.

Recorded data included name, age, sex, test result, type of bacteria, and pattern of drug resistance or susceptibility. Annual data were 3071 urine tests that formed the sample size of study.

Inclusion criteria included all patients whose urine culture was positive and antibiograms were available, and exclusion criteria included incomplete tests.

Finally, SPSS statistical software (version 22) was used to analyze the collected data.

\section{RESULTS}

2260 (73.59\%) were female and 811 (26.41\%) were male. Of these, $252(8.2 \%)$ tested positive. The study age groups included 394 people in the age range of $1-15$ years, 583 people in the age range of $16-30$ years, 1113 people in the age range of $31-60,610$ people in the age range of $61-70$ years and 371 people in the age range of over 70 years.

The lowest frequency of referrals was related to April with 103 cases. 52 positive tests were observed in spring (21\%), 78 positive tests in summer (31\%), 55 positive tests in autumn $(22 \%)$ and 67 positive tests in winter (26\%). Of the 252 positive tests, 201 were for women and 51 were for men.

Escherichia coli had the highest frequency (130 cases or $52 \%$ ). The second infection common agent in patients was Klebsiella pneumoniae. Also, the lowest prevalence was observed about Pseudomonas (Table 1).

Table 1: Frequency of bacterial contamination in positive samples based on month

\begin{tabular}{|c|c|c|c|c|c|c|c|}
\hline \multirow[b]{2}{*}{ Month } & \multicolumn{7}{|c|}{ Bacteria } \\
\hline & E. coli & Klebsiella & Staph. & Citrobacter & Entrococcus & Streptococcus & Pseudomonas \\
\hline April & 6 & 2 & 0 & 0 & 0 & 0 & 0 \\
\hline May & 11 & 3 & 2 & 0 & 0 & 1 & 1 \\
\hline June & 16 & 3 & 2 & 1 & 2 & 1 & 1 \\
\hline July & 11 & 5 & 1 & 2 & 1 & 0 & 1 \\
\hline August & 9 & 7 & 3 & 2 & 3 & 3 & 0 \\
\hline September & 15 & 6 & 3 & 2 & 3 & 1 & 0 \\
\hline October & 15 & 1 & 2 & 0 & 2 & 1 & 1 \\
\hline November & 9 & 5 & 1 & 0 & 0 & 0 & 0 \\
\hline December & 10 & 3 & 1 & 1 & 1 & 2 & 0 \\
\hline January & 8 & 3 & 3 & 3 & 3 & 2 & 2 \\
\hline February & 12 & 3 & 4 & 1 & 4 & 2 & 1 \\
\hline March & 8 & 1 & 4 & 0 & 2 & 1 & 0 \\
\hline Total & 130 & 42 & 26 & 12 & 21 & 14 & 7 \\
\hline
\end{tabular}

The results showed that in the studied samples, the lowest resistance was related to gentamicin and the highest resistance was related to ampicillin (Table 2).

Table 2: Frequency of antibiotic resistance pattern in the study population

\begin{tabular}{|l|l|l|l|}
\hline Antibiotic & Resistance & Susceptibility & Intermediate \\
\hline Ciprofloxacin & 51 & 188 & 13 \\
\hline Ampicillin & 185 & 56 & 11 \\
\hline Nalidixic Acid & 171 & 69 & 12 \\
\hline Nitrofurantoin & 61 & 182 & 9 \\
\hline Gentamycin & 23 & 225 & 4 \\
\hline Co-trimoxazole & 68 & 178 & 6 \\
\hline Ceftizoxim & 43 & 196 & 13 \\
\hline Total & 602 & 1094 & 67 \\
\hline
\end{tabular}

The result of the urine test most likely depended on age and gender (Tables 3, 4).

Table 3: Relationship between urine test and age

\begin{tabular}{|l|l|l|l|l|}
\hline \multirow{2}{*}{$\begin{array}{l}\text { Age Group } \\
\text { (year) }\end{array}$} & \multicolumn{2}{|l|}{ Test result } & Total & P-value \\
\cline { 2 - 3 } & Positive & Negative & & \\
\hline $1-15$ & 43 & 351 & 394 & 0.00001 \\
\hline $16-30$ & 37 & 546 & 583 & \\
\hline $31-60$ & 62 & 1051 & 1113 & \\
\hline $61-70$ & 58 & 552 & 610 & \\
\hline$>70$ & 52 & 319 & 371 & \\
\hline Total & 252 & 2819 & 3071 & \\
\hline
\end{tabular}


Table 4: Relationship between urine test and gender

\begin{tabular}{|l|l|l|l|l|}
\hline \multirow{2}{*}{ Gender } & \multicolumn{2}{|l|}{ Test result } & \multirow{2}{*}{ Total } & \multirow{2}{*}{ P-value } \\
\cline { 2 - 3 } & Positive & Negative & & \\
\hline Male & 51 & 760 & 811 & 0.021 \\
\hline Female & 201 & 2059 & 2260 & \\
\hline Total & 252 & 2819 & 3071 & \\
\hline
\end{tabular}

\section{DISCUSSION}

In current study, $8.2 \%$ cases were positive. Also, the highest frequency was related to 31-60 age group. The lowest frequency of referrals was related to April. More positive cases were associated with summer. Escherichia coli had the highest frequency. The lowest resistance was related to gentamicin and the highest resistance was related to ampicillin. A study in western Mumbai from 2008-2010 was performed. Almost $60 \%$ cases examined had positive culture. E.coli was the most usual agent. Also, the sensitivity amount to gentamicin was very high. This study was similar to current study specially about dominant isolate that was E.coli ${ }^{[1]}$.

Another study results in Islamabad, Pakistan showed that E.coli was the most bacterial isolate. E. coli exhibited the highest sensitivity to amikacin [8]. In current study, the highest susceptibility was related to gentamicin. A study in Sudan also displayed that the most urinary pathogen was E.coli and the highest level of resistance was associated with ampicillin [20]. The current study also demonstrated the high resistance to ampicillin.

In Ethiopia investigating antimicrobial susceptibility exhibited that the most common bacterial agent isolated from samples was E.coli and the highest resistance was related to ampicillin [17]. This study was also similar to current study in both these subjects (bacteria and antibiotic).

\section{CONCLUSION}

In this study, almost $8 \%$ of cases had positive test. The lowest incidence of referrals was associated with April. The positive cases were more in summer. Escherichia coli had the highest incidence. The highest resistance was related to ampicillin. Thus, it is important that ampicillin should be used lesser in urinary infection caused by Escherichia coli in ShahreKord.

\section{Acknowledgement}

The authors like to acknowledge infectious diseases research center of Yazd, Iran for their aid.

\section{Conflict of Interest}

We declare that we have no conflict of interest.

\section{Financial Support}

None declared.

\section{REFERENCES}

1. Nerurkar A, Solanky $P$, Naik SS. Bacterial pathogens in urinary tract infection and antibiotic susceptibility pattern. Journal of Pharmaceutical and Biomedical Sciences. 2012; 21(21).
2. Ammenti A, Alberici I, Brugnara M, Chimenz R, Guarino S, La Manna $A$, et al. Updated Italian recommendations for the diagnosis, treatment and follow-up of the first febrile urinary tract infection in young children. Acta Paediatr. 2020; 109(2):236-47.

3. Praetorius $\mathrm{H}$. The Bacteria and the Host: A Story of Purinergic Signaling in Urinary Tract Infections. American Journal of Physiology-Cell Physiology. 2021.

4. AL-Khikani FHO, Abadi RM, Ayit AS. Emerging carbapenemase Klebsiella oxytoca with multidrug resistance implicated in urinary tract infection. Biomedical and Biotechnology Research Journal (BBRJ). 2020; 4(2):148.

5. Eremenko R, Barmatz S, Lumelsky N, Colodner R, Strauss M, Alkan Y. Urinary Tract Infection in Outpatient Children and Adolescents: Risk Analysis of Antimicrobial Resistance. The Israel Medical Association journal: IMAJ. 2020; 22(4):236-40.

6. Hasan AS, Nair D, Kaur J, Baweja G, Deb M, Aggarwal P. Resistance patterns of urinary isolates in a tertiary Indian hospital. Journal of Ayub Medical College Abbottabad. 2007; 19(1):39-41.

7. Ahmadzadeh A, Askarpour S. Association of urinary tract abnormalities in children with first urinary tract infection. Pakistan journal of medical sciences. 2007; 23(1):88.

8. Kalsoom B, Jafar K, Begum H, Munir S, ul AKBAR N, Ansari JA, et al. Patterns of antibiotic sensitivity of bacterial pathogens among urinary tract infections (UTI) patients in a Pakistani population. African Journal of Microbiology Research. 2012; 6(2):414-20.

9. Klein RD, Hultgren SJ. Urinary tract infections: microbial pathogenesis, host-pathogen interactions and new treatment strategies. Nature Reviews Microbiology. 2020; 18(4):211-26.

10. Rodriguez-Mañas L. Urinary tract infections in the elderly: a review of disease characteristics and current treatment options. Drugs in Context. 2020; 9.

11. Hossain A, Hossain SA, Fatema AN, Wahab A, Alam MM, Islam $\mathrm{MN}$, et al. Age and gender-specific antibiotic resistance patterns among Bangladeshi patients with urinary tract infection caused by Escherichia coli. Heliyon. 2020; 6(6):e04161.

12. Hvidberg H, Struve C, Krogfelt KA, Christensen N, Rasmussen SN, Frimodt-Møller N. Development of a long-term ascending urinary tract infection mouse model for antibiotic treatment studies. Antimicrob Agents Chemother. 2000; 44(1):156-63.

13. Al-Jebouri MM, Mdish SA. Antibiotic resistance pattern of bacteria isolated from patients of urinary tract infections in Iraq. 2013.

14. Etta PK. Urinary tract infections in kidney transplantation: An emerging crisis of drug resistance. Indian Journal of Transplantation. 2020; 14(4):283.

15. Ajani TA, Elikwu CJ, Nwadike VU, Tayo B, Shonekan OA, Okangba CC, et al. Urinary tract infections and antimicrobial susceptibility pattern among female students in a tertiary institution in southwest Nigeria-A cross sectional study. Journal of Clinical Sciences. 2020; 17(4):131.

16. Farajnia S, Alikhani MY, Ghotaslou R, Naghili B, Nakhlband A. Causative agents and antimicrobial susceptibilities of urinary tract infections in the northwest of Iran. Int J Infect Dis. 2009; 13(2):1404.

17. Beyene G, Tsegaye W. Bacterial uropathogens in urinary tract infection and antibiotic susceptibility pattern in jimma university specialized hospital, southwest ethiopia. Ethiopian journal of health sciences. 2011; 21(2):141-6.

18. Motbainor H, Bereded F, Mulu W. Multi-drug resistance of blood stream, urinary tract and surgical site nosocomial infections of Acinetobacter baumannii and Pseudomonas aeruginosa among patients hospitalized at Felegehiwot referral hospital, Northwest Ethiopia: a cross-sectional study. BMC Infect Dis. 2020; 20(1):111.

19. Bazzaz BSF, Fork SD, Ahmadi R, Khameneh B. Deep insights into urinary tract infections and effective natural remedies. African Journal of Urology. 2021; 27(1):1-13.

20. Ahmed AA, Osman H, Mansour AM, Musa HA, Ahmed AB, Karrar $Z$, et al. Antimicrobial agent resistance in bacterial isolates from patients with diarrhea and urinary tract infection in the Sudan. The American journal of tropical medicine and hygiene. 2000; 63(56):259-63. 